\title{
MAKNA FILOSOFIS DALAM PAGELARAN KESENIANSINTREN DI SANGGAR SEKAR INSANI CIREBON
}

\author{
Eka Wati \\ Institut Agama Islam Negeri Syekh Nurjati Cirebon
}

\begin{abstract}
Abstrak: Penelitian ini membahas tentang Filsafat Nilai Pertunjukan Kesenian Sintren (Studi Kasus Sanggar Sintren Sekar Insani desa Babadan, Gunungjati, Kabupaten Cirebon). Cirebon adalah kota yang kaya akan kesenian dan budaya. Cirebon memiliki banyak kesenian dan budaya diantaranya yaitu sintren. Pertunjukan kesenian sintren syarat akan nilai-nilai filosofis. Nilai-nilai filosofis tersebut ada dalam unsur-unsur yang ada dalam pertunjukan kesenian sintren. Dalam pementasan kesenian sintren sangat banyak pesan-pesan yang terselubung yang mengandung nilai-nilai falsafah keagamaan, dapat dilihat pada saat pementasannya, gerakan tariannya, lagu-lagu yang dinyanyikan, alat musik yang digunakan semua itu mengandung unsur keagamaan agar penonton mudah menangkap pesan kesan yang ingin disampaikan dalam pertunjukan kesenian sintren tersebut. Selain sebagai tontonan, pertunjukan kesenian sintren juga berfungsi sebagai tuntunan. Pesan-pesan simbolik di setiap adegannya mengandung unsur-unsur pendidikan. Tujuan diadakannya penelitian ini yaitu untuk mengetahui dan mengidentifikasi falsafah nilai yang terdapat dalam kesenian Sintren, untuk menambah wawasan tentang kesenian dan kebudayaan terutama kesenian Sintren.Penelitian ini menggunakan pendekatan deskriptif kualitatif, maka kehadiran penelitian ini observasi di lapangan dan wawancara sangat penting. Data yang berbentuk hasil wawancara yang diperoleh dari para informan, sedangkan data tambahan berupa dokumen. Analisis data dilakukan dengan cara menelaah data yang ada.
\end{abstract}

Kata Kunci: Sintren, Sanggar Sintren Sekar Insani, Nilai-Nilai Filosofis.

\section{A. PENDAHULUAN}

Cirebon adalah kota yang kaya akan kesenian dan budaya. Cirebon memiliki banyak kesenian dan budaya diantaranya wayang kulit, topeng, sintren, berokan, tayuban, masres, tarling dan lain sebagainya. Budaya merupakan suatu pola hidup yang terus berkembang dalam kehidupan masyarakat dan sangat erat hubungannya dengan masyarakat, masyarakat berkewajiban untuk menjaga, memelihara dan melestarikannya sehingga budaya masih bisa diwariskan secara turun temurun dari generasi ke generasi. Budaya tersusun dari beberapa unsur penting yang meliputi adat 
istiadat, bahasa, agama, politik, hukum dan kesenian ${ }^{1}$. Perwujudan dari kebudayaan misalnya saja benda-benda, perilaku masyarakat dan berbagai macam karya kesenian hasil ciptaan masyarakat yang bertujuan untuk membantu masyarakat dalam melangsungkan kehidupannya sehari-hari. Budaya adalah konsep, keyakinan, nilai dan norma yang dianut masyarakat yang mempengaruhi perilaku mereka dalam upaya menjawab tantangan kehidupan yang berasal dari alam sekelilingnya. ${ }^{2}$

Tidak terlepas dari ciri khas yang dimiliki Cirebon yang sangat dominan dalam bidang walisongo yang kental akan ajaran tasawuf dan kesenian. Melalui falsafah nilai yang terkandung dalam suatu kesenian, sering kali kesenian digunakan masyarakat sebagai media dakwah penyebaran agama Islam yang masih dilestarikan hingga sekarang. Kesenian memudahkan masyarakat untuk menyebarluaskan ajaran agama Islam melalui pagelaran yang ditujukan untuk masyarakat umum dengan harapan selain masyarakat menikmati unsur hiburannya, masyarakat juga dapat menangkap unsur didikan kesan pesan religi yang terdapat dalam pagelaran kesenian tersebut tidak lain yaitu untuk merubah masyarakat menjadi manusia yang lebih baik lagi dari sebelumnya. Manusia mempunyai bahasa untuk berinteraksi terhadap sesama sehingga menunjang kelancaran pertumbuhan dan perkembangan kebudayaan. ${ }^{3}$

Kesenian yang biasa digunakan dalam bidang keagamaan misalnya saja wayang kulit, sintren, berokan, topeng, ronggeng atau tayuban. Dalam dunia tasawuf sintren dan wayang digambarkan sama halnya dengan tingkatan syariat, berokan menggambarkan tingkatan tarekat, topeng menggambarkan tingkatan syariat dan berokan atau tayuban yang menggambarkan tingkatan hakikat. Nilai-nilai yang terkandung dalam

\footnotetext{
${ }^{1}$ Ryan Prayogi dan Endang Danial. Pergeseran Nilai-Nilai Budaya pada Suku Bonai sebagai Civic Culture di Kecamatan Bonai Darussalam Kabupaten Rokan Hulu Provinsi Riau. HUMANIKA Vol. 23 No. 1 (2016).

${ }^{2}$ Rusmin Tumanggor dkk, Ilmu Sosial dan Budaya Dasar (Kencana: Jakarta, 2012), 141.

${ }^{3}$ Rohiman Notowidagdo, Ilmu Budaya Dasar (PT.RajaGrafindo Persada: Jakarta, 2000), 29.
} 
kesenian-kesenian tersebut sama halnya dengan tingkatan-tingkatan seorang sufi dalam tasawuf untuk mencapai predikat manusia yang sempurna dan menggapai ridha Allah dalam menjalani kehidupan ini. Kesenian-kesenian tersebut merupakan unsur pokok dalam penyebaran syiar Islam di Cirebon. Kesenian lainnya hanya merupakan kesenian pelengkap dari kesenian-kesenian tersebut. Setiap kesenian memiliki nilai filsofis, nilai-nilai tersebut menyangkut masalah-masalah pokok dalam kehidupan manusia. ${ }^{4}$

Sintren adalah kesenian tradisional yang tumbuh dan berkembang di kalangan masyarakat Cirebon. Sintren merupakan kesenian yang sederhana dengan menggunakan perlengkapan yang sederhana. Sintren terdiri dari dua suku kata yaitu Sinyo yang berarti pemuda dan trennen yang berarti berlatih. Secara etimologi Sintren merupakan gabungan dari dua suku kata yaitu $S i$ yang berarti ia atau dia dan Tren berarti tri atau panggilan lain kata putri. Sehingga Sintren adalah Si Putri yang menjadi pemeran utama dalam kesenian sintren. ${ }^{5}$ Sintren mulai diperkenalkan di kalangan masyarakat sekitar tahun 1940, Sintren merupakan bagian dari cerita rakyat yang dalam pagelaran pementasannya seorang penari menari dengan gerak ritmik sangat indah dalam kondisi tidak sadarkan diri seperti halnya fana yang dilakukan oleh para sufi. Kesenian sintren terus berkembang mengikuti arus perkembangan zaman. ${ }^{6}$

Kesenian Sintren tumbuh dan berkembang mengikuti kemajuan zaman. Sebelumnya sintren digunakan sebagai media untuk mengusir para penjajah, pada zaman animisme dan dinamisme sintren digunakan sebagai alat untuk mendekatkan diri dan berkomunikasi dengan arwah para leluhur. Namun pada zaman perkembangan agama Islam di Cirebon Sintren

${ }^{4} \mathrm{Ibid}, .40$.

${ }^{5}$ Aliet Noorhayati, Metafisika dalam Tarian Sintren (Filsafat Pantura) (Jurnal Yaqzan: IAIN Syekh Nurjati, 2015), 374.

${ }^{6}$ Laksmiwati, Rumah Budaya Nusantara Pesambangan Jati Cirebon (Deepublish: Yogyakarta, 2013), 1. 
digunakan sebagai media dakwah dalam penyebaran agama Islam. Para wali menyebarkan agama Islam dengan memanfaatkan sarana kesenian sintren sebagai salah satu kesenian tradisional yang dijadikan media dakwah Islam di Cirebon dan sekitarnya. Dalam pementasan keenian sintren sangat banyak pesan-pesan yang terselubung yang mengandung nilai-nilai falsafah keagamaan, dapat dilihat pada saat pementasannya, gerakan tariannya, lagulagu yang mengandung dinyanyikan, alat musik yang digunakan semua itu mengandung unsur keagamaan agar penonton mudah menangkap pesan kesan yang ingin disampaikan dalam pertunjukan kesenian sintren tersebut. Selain sebagai tontonan, pertunjukan kesenian sintren juga berfungsi sebagai tuntunan. Pesan-pesan simbolik di setiap adegannya mengandung didikan, terutama didikan untuk para generasi muda, membentuk karakter masyarakat dan sebagai salah satu bentuk dari pencerahan masyarakat. ${ }^{7}$

Pagelaran kesenian sintren sekarang ini jarang sekali dipentaskan, hanya di peringatan tertentu dan hari-hari besar saja sintren di pentaskan. Sanggar sintren Sekar Insani adalah salah satu sanggar yang masih aktif dalam melakukan pertunjukan Sintren, sering kali ikut berpartisipasi dalam mengisi acara-acara tertentu. Anggota sanggar sintren Sekar Insani yang mayoritas para pelajar sekolah menengah menjadikan sanggar sintren Sekar Insani sebagai wadah untuk mendidik para generasi muda agar lebih mencintai kesenian khas Cirebon ditengah pesatnya era globalisasi saat ini. Kesenian sintren merupakan kekayaan budaya yang bernilai luhur, yang merupakan media dakwah bagi sebagian kalangan. ${ }^{8}$

Kesenian sintren sama halnya dengan kesenian lainnya yang digunakan sebagai media dakwah islam misalnya saja kesenian wayang dan tari topeng, sebagai media islamisasi memiliki konsep yang ingin dijelaskan kepada masyarakat melalui pementasannya, diantaranya yaitu konsep tasawuf. Tasawuf berasal dari kata Shafa' yang artinya suci. Maksudnya

${ }^{7}$ Ibid,. 3.

${ }^{8}$ Ibid,. 51 . 
ialah mensucikan diri dihadapan Tuhan dengan latihan berat dan lama. Tasawuf juga berasal dari kata shuf yang berarti kain wol kasar. Maksudnya ialah para sufi itu hidupnya sederhana, berhati mulia, menjauhi pakaian sutera dan memakai wol kasar. ${ }^{9}$ Tasawuf ialah mendekatkan diri kepada Allah dengan beribadah membersihkan diri dari sifat-sifat tercela, menghias diri dengan sifat-sifat terpuji, tidak mementingkan urusan dunia, merasa cukup atas segala pemberian Allah atas dirinya disertai tawakal dan mahabbah kepada Allah. ${ }^{10}$ Kesenian sintren mendialogkan nilai-nilai tasawuf dalam pementasannya agar dengan mudah dapat ditangkap oleh masyarakat melalui tarian, lagu, alat musik dan para pemainnya. Pertunjukan sintren saat ini telah mengubah syair-syair non islam menjadi syair-syair Islam. ${ }^{11}$

Cirebon memiliki beberapa sanggar sintren diantaranya yaitu sanggar sintren sekar insani di desa Babadan Gunungjati, sanggar seni sekar pandan di kraton Kacirebonan, sanggar seni kencana ungu. Namun, penulis memilih sanggar sintren sekar insani desa Babadan Gunungjati karena sanggar sintren sekar insani mayoritas anggotanya adalah generasi muda sekaligus peserta didik di yayasan bhakti insani. Generasi muda merupakan agen terpenting dalam pelestarian kesenian dan budaya kita ini. Melalui generasi muda kita dapat menanamkan sikap cinta pada budaya yang kita miliki. Sanggar sintren sekar insani sekarang ini masih ditampilkan untuk acara-acara tertentu dan peringatan hari besar nasional dan peringatanperingatan hari besar keagamaan.

\section{B. METODE PENELITIAN}

Metode yang digunakan dalam penelitian ini yaitu metode kualitatif, dalam penelitian ini terdapat dua tahap analisis yaitu analisis teks tembang

\footnotetext{
${ }^{9}$ Samsul Munir Amin, Ilmu Tasawuf (Jakarta: AMZAH, 2012) 3.

${ }^{10}$ Labib, Memahami Ajaran Tashawwuf (Surabaya: Bintang Usaha Jaya, 2001) 14.

${ }^{11}$ Laksmiwati, Rumah Budaya Nusantara Pesambangan Jati Cirebon (Deepublish: Yogyakarta, 2013), 12.
} 
dan analisis fungsi tembang. Hasil penelitian ini diperoleh fungsi tembang yaitu ritual, didaktis, protes sosial, dan hiburan. Fungsi ritual berkaitan dengan pemanggilan roh gaib untuk masuk ke tubuh sintren dan bodor serta setelah selesai dikeluarkan kembali dari tubuh anak-anak tersebut. Fungsi didaktis dalam tembang ini ialah mengajak penikmat tembang untuk memandang hidup lebih bijaksana agar diperoleh keselarasan hidup. Fungsi protes sosial berisi imbauan agar tidak meremehkan kaum perempuan. Penyampaian ketiga fungsi tersebut adalah melalui aspek hiburan yang dikemas dalam satu pertunjukan yaitu pertunjukan sintren.

\section{HASIL DAN PEMBAHASAN}

Sanggar sintren sekar Insani merupakan salah satu sanggar sintren yang ada di wilayah Cirebon. Sanggar ini terdapat di desa Babadan, Gunungjati Kabupaten Cirebon. Menurut tradisi lisan, asal kata nama desa Babadan berasal dari mitos masyarakat. Sekitar abad ke-14, ada seorang puteri yang berasal dari Aceh yang benama Nyi Babadan. Nyi Babadan memiliki nama asli Celangkring. Celangkring merupakan nama pohon, sejenis pohon Dadap, karena di wilayah tersebut banyak terdapat pohon Cangkring. Secara etimologi Sintren merupakan gabungan dari dua suku kata yaitu $S i$ yang berarti ia atau dia dan Tren berarti tri atau panggilan lain kata putri. Sehingga Sintren adalah Si Putri yang menjadi pemeran utama dalam kesenian sintren. Sintren mulai diperkenalkan di kalangan masyarakat sekitar tahun 1940, Sintren merupakan bagian dari cerita rakyat yang dalam pagelaran pementasannya seorang penari menari dengan gerak ritmik sangat indah dalam kondisi tidak sadarkan diri seperti halnya fana yang dilakukan oleh para sufi. Kesenian sintren terus berkembang mengikuti arus perkembangan zaman.

Unsur-unsur yang terdapat dalam pertunjukan kesenian sintren diantaranya yaitu tari, syair lagu, alat musik yang memiliki nilai-nilai filosofis. 
1. Nilai-nilai Filosofis yang terdapat pada pertunjukan kesenian sintendiantaranya yaitu:

a. Gerakan

Gerakan tarian sintren memiliki nilai filosofis dari kecantikan seorang wanita. Tariannya yang lemah gemulai merupakan dasar daripada sifat wanita yang anggun dan lemah gemulai. Pada adegan sintren yang terjatuh saat dilempari uang oleh penonton, merupakan simbol dari manusia yang terjatuh karena terlalu mencintai duniawi. Kacamata hitam yang dipai sintren merupakan simbol dari kegelapan seorang manusia apabila terlalu mencintai dunia. adegan sintren yang diikat dan dimasukkan kedalam kurungan setelah beberapa waktu sintren yang dimasukkan ke dalam kurungan dalam kondisi badan terikat tali sintren keluar dari kurungan sudah berubah menjadi gadis cantik yang sudah tidak terbelenggu adalah simbol manusia yang dimasukkan ke alam kubur. Sintren yang diikat adalah simbol manusia yang terikat dengan pertanyaan-pertanyaan di alam Barzah. Malaikat Munkar dan Nakir akan menyampaikan pertanyaan siapa Tuhanmu, siapa nabimu, apa agamamu, siapa imammu, apa kitabmu dan siapa saudaramu. Bila satu pertanyaan itu dapat dijawab dengan benar maka akan terlepas satu ikatan, begitu juga seterusnya sampai tali ikatan akan terlepas semua dan mendapatkan kebebasan hukuman di alam barzah. ${ }^{12}$ Dan Kurungan dan Sintren, melambangkan badan jasmani dan rohani, yang pada waktunya dengan ketentuan Allah akan ditinggalkan oleh badan rohani, seperti kurungan ditinggalkan oleh pawang sintren. ${ }^{13}$

b. Syair-syair Lagu

Syair-syair lagu yang dibawakan oleh para pesinden dalam pertunjukan kesenian sintren memiliki nilai-nilai filosofis diantaranya yaitu:

${ }^{12}$ Dyah Komala Laksmiwati dkk, SINTREN (Rumah Budaya Nusantara Pesambangan Jati Cirebon: Cirebon), 45.

${ }^{13}$ Laksmiwati, Rumah Budaya Nusantara Pesambangan Jati Cirebon (Deepublish: Yogyakarta, 2013), 8. 
1) Mengandung syiar ajaran agama Islam. Seperti yang terdapat pada lirik syair lagu berikut ini:

Wari lais terapnang sandang ira

Dunung alah dunung

Si Dununge bahu kiwa

Pangeran kang lara tangis
Pawang lais pasangkan pakaianmu

Majikan duh majikan

Majikannya bahu kiri

Tuhan yang pengasih-penyayang ${ }^{14}$

Wari lais adalah sintren yang melambangkan manusia. Terapnang sandang ira melambangkan segala kehendak manusia. Dunung atau majikan adalah Allah SWT yang wajib disembah. Si Dununge bahu kiwa maksudnya adalah Tuhan tidak jauh dari kita, Tuhan selalu mengetahui segala apa yang kita lakukan. Pangeran kang lara tangis memiliki makna bahwa Tuhan yang Maha Pengasih dan Penyayang sebagai tempat kita mengabdi dan memohon segala pertolongan.Secara sosiologis, agama berarti tradisi. Sebagai penuntun umat manusia, pada dasarnya semua agama mengajarkan kebaikan, kedamaian, keselamatan. ${ }^{15}$ Lain pendapat dengan Durkheim yang menyatakan bahwa agama adalah sistem yang menyatu mengenai berbagai kepercayaan dan peribadatan yang berkaitan dengan benda-benda sakral. ${ }^{16}$ Agama merupakan sistem kepercayaan dan peribadatan yang digunakan oleh berbagai bangsa dalam perjuangan mereka untuk mengatasi persoalan-persoalan tertinggi dalam kehidupan manusia. ${ }^{17}$ Agama ialah suatu jenis sistem sosial yang dibuat oleh penganutpenganutnya yang berporos pada kekuatan-kekuatan non empiris yang dipercayainya dan didayagunakannya untuk mencapai keselamatan bagi

\footnotetext{
${ }^{14}$ Ibid,. 9 .

15 Ahmad Kholil, Agama (Kultural) Masyarakat Pinggiran (UIN-MALIKI PRESS: Malang, 2011), 49.

${ }^{16}$ Betty R. Scharf, Sosiologi Agama (Prenada Media: Jakarta Timur, 2004), 34.

${ }^{17}$ Ibid,. 35 .
} 
diri mereka dan masyarakat umumnya. ${ }^{18}$ Agama dalam konteks sosial budaya masyarakat Jawa dipahami sebagai sistem keyakinan dan ritual yang berbeda dengan tradisi pada umumnya, dimana Islam mengislamkan budaya pribumi dan mensyiarkan nilai-nilai kebaikan yang terdapat dalam Al-Qur'an. ${ }^{19}$

Pada masa penyebaran ajaran agama Islam, syair-syair lagu yang sebelumnya terdapat nilai animisme dan dinamisme yang ada dalam pertunjukan kesenian sintren dirubah menjadi syair-syair islami. Penyebaran ajaran agama Islam pada waktu itu mengalami banyak tantangan. Penyebaran ajaran agama Islam melalui media kesenian merupakan salah satu cara agar ajaran Islam mudah diterima oleh masyarakat pada saat itu mayoritas menganut kepercayaan hindu budha. Dengan menyisipkan nilainilai ajaran agama Islam, masyarakat dapat menerima dengan baik datangnya agama Islam dikalangan masyarakat tersebut. Kesenian sintren pada masa penyebaran agama Islam memiliki nilai-nilai falsafah ajaran Islam yang ingin disampaikan kepada para masyarakat.

1. Semangat Perjuangan Kemerdekaan Indonesia

Perkembangan sintren pada zaman penjajahan Belanda, Inggris dan Jepang sampai pada zaman setelah Indonesia merdeka dapat dimaknai sebagai suatu simbol. Pada zaman penjajahan Belanda, kesenian sintren tidak lepas dari kekuasaan penjajah. Seperti yang terdapat pada lirik syair lagu berikut ini:

Duwit-duwit gembring

Si... numbak celeng

Keris mlengkung. Tumbak mlengkung

${ }^{18}$ Hendropuspito, Sosiologi Agama (Kanisius: Yogyakarta, 1983), 34.

19 Ahmad Kholil, Agama (Kultural) Masyarakat Pinggiran (UIN-MALIKI PRESS: Malang, 2011), 65. 
Si.. ditilikung

Ciyet, ciyet di.... dibebencet

Syair lagu diatas adalah lagu ciptaan Belanda untuk menghina para pejuang, pahlawan pemberontakan penjajah, haya diubah sedikit dari aslinya. Para penjajah menganggap pahlawan Indonesia hanya Duwit gembring ${ }^{20}$ yang tidak bernilai dan tidak berguna tidak mungkin akan mengalahkan penjajah dan sangat sedikit kemungkinan untuk bisa merdeka dari para penjajah. Pada adegan sintren yang terbelenggu oleh tali melambangkan kondisi bangsa Indonesia yang saat itu masih terbelenggu dalam kungkungan penjajah. Dengan tangan terbelenggu gerak kita juga sangat terbatas. Kacamata hitam yang dipakai oleh sintren sama halnya dengan bangsa Indonesia yang tidak dapat melihat dan memilih jalan. Sintren yang terbelenggu dengan tali dimasukkan ke dalam kurungan memiliki makna bahwa kalau kita dapat terbebas dari belenggu para penjajah maka kita akan segera merdeka. Dengan adanya pertunjukan sintren pada saat penjajahan, diharapkan para masyarakat memiliki kesadaran untuk terbebas dari kungkungan para penjajah dan segera mencapai kemerdekaan bangsa Indonesia.

2. Masa Animisme dan Dinamisme

Sintren merupakan peninggalan nenek moyang zaman animisme dan dinamisme. Animisme berasal dari kata anima yang berarti ajaran atau doktrin tentang realitas jiwa. $^{21}$ Menurut Tylor, animisme adalah perlambangan dari suatu jiwa atau roh pada beberapa makhluk hidup dan objek bernyawa lainya. ${ }^{22}$ Animisme merupakan kepercayaan masyarakat terhadap roh-roh. Animisme terutama tersebar diantara golongan penduduk yang hidup dari pertanian. Animisme mengisi kekosongan

${ }^{20}$ Duwit gembring adalah uang recehan yang tidak bernilai dan tidak berguna.

${ }^{21}$ Zakiah Daradjah, Perbandingan Agama 1 (IAIN Jakarta: Jakarta, 1982), 25.

${ }^{22}$ Ibid,. 27. 
iman ketuhanan dengan menghayalkan dewa-dewi dan roh pengantara. ${ }^{23}$ Sedangkan dinamisme berasal dari bahasa Yunani yaitu Dunamos yang diingriskan menjadi Dynamic apabila diartikan kedalam bahasa Indonesia memiliki arti kekuatan, kekuasaan, khasiat atau daya. Dinamisme merupakan sejenis paham dan perasaan keagamaan yang terdapat di berbagai bagian dunia, pada berjenis-jenis bangsa yang menunjukan banyak persamaan-persamaan. ${ }^{24}$

\section{Masa Hindu Budha}

Pertunjukan sintren sangat berpengaruh pada masa Hindu Budha, seperti yang tercermin pada lirik syair berikut ini:

Kembang Jahe Laos Bunga jahe laos

Kecampur kembang kemuning Kecampur bunga kemuning

Arep balik gage elos Mau pulang silahkan pergi

Mengko sore menea maning Nanti sore kesini lagi ${ }^{25}$

Kata balik dalam lirik syair diatas memiliki arti mati atau meninggalkan dunia, sedangkan kata menea maning memiliki arti kembali lagi, menitis kembali atau lahir kembali. Dalam keyakinan agama Hindu budha dikenal istilah reinkarnasi. ${ }^{26}$

2) Inkulturasi Kesenian Sintren

Dalam Penelitian ini, penulis mengacu pada teori filsafat kebudayaan J.W.M Bakker SJ, karena teori ini memiliki kesamaan dengan yang akan penulis teliti, dimana Inkulturasi dimaknai sebagai pembinaan kebudayaan melalui proses-proses asasi. Inkulturasi diartikan sebagai

\footnotetext{
${ }^{23}$ R.Subagya, Agama Asli Indonesia (Sinar Harapan: Jakarta, 1979), 76.

${ }^{24}$ Zakiah Daradjat, Perbandingan Agama 1 (Bumi Aksara: Jakarta, 1996), 98.

${ }^{25}$ Ibid,. 7.

${ }^{26}$ Charim Suparto, Deskripsi Kesenian Daerah Cirebon (Dinas Kebudayaan, Pariwisata, Pemuda dan Olahraga Kabupaten Cirebon: Sumber, 2009), 212.
} 
latihan, berkat mana seorang individu diintegrasikan kedalam kebudayaan sezaman dan setempat ${ }^{27}$ dan warisan kebudayaan tidak dipartisipasikan sebagai beban, melainkan sebagai perkaya individu. ${ }^{28}$ Seperti halnya pertunjukan kesenian sintren yang setiap waktu dapat dimaknai berbeda sesuai dengan konteks masyarakat yang sedang terjadi pada saat itu. Misalnya saja pertunjukan kesenian sintren di masa sebelum kemerdekaan memiliki pesan-pesan moral yang disampaikan yang berbeda dengan pertunjukan kemerdekaan setelah kemerdekaan, pertunjukan kesenian sintren terus mengalami perubahan seiring dengan berjalannya waktu disesuaikan dengan kondisi soal yang sedang terjadi saat itu. baik dalam penyajian pertunjukannya maupun pesan-pesan moral atau ajaran agama yang disampaikannya selalu menghubungkan dengan kondisi sosial yang sedang terjadi saat itu tanpa mengurangi sisi keindahan dari pertunjukan kesenian sintren tersebut. Dalam perkembangannya, sintren mengalami perbedaan pemaknaan dari zaman ke zaman. Pemaknaan atau pesan moral pertunjukan sintren di kondisikan sesuai dengan yang sedang terjadi pada saat itu. Seperti halnya sintren yang dipertunjukan pada masa animisme dinamisme akan mengalami perbedaan pemaknaan pada saat zaman penyebaran agama Islam ataupun pada zaman penjajahan.

Menurut A. Opan Safari, sintren adalah manusia yang terbelenggu oleh duniawi. Manusia yang ingin terbebas oleh belenggu duniawi harus masuk ikatan tertentu bisa melalui masuk ke dalam tarekat-tarekat atau atau jamiah dzikir tertentu untuk melakukan latihan-latihan spiritual agar menjadi Insan Kamil. Insan Kamil Harus terbebas dari penghambaan kepada selain Allah. Manusia yang sudah terbebas dari belenggu duniawi ia akan seperti kupu-kupu yang sedang bermetamorfosis, unutk menjadi kupu-kupu yang indah harus melewati fase-sase terlebih dahulu. Sama halnya orang

${ }^{27}$ J.W.M.Bakker.SJ, Filsafat Kebudayaan: Sebuah Pengantar, Yogyakarta: PT.Kanisius. 1984. Hlm.103.

${ }^{28}$ Ibid, Hlm. 111. 
Islam yang sedang berpuasa di bulan Ramadhan, setelah satu bulan penuh berpuasa maka akan diampuni dosa-dosanya sama halnya bayi yang baru dilahirkan dengan keadaan suci, dengan busana baru dan dengan iman yang terbaharui. $^{29}$

Pada masa perjuangan khususnya perjuangan Pangeran Aria Pengenah Abu Hayat Surya Kusuma tahun 1773-1777 berjuang menentang belanda. Sintren merupakan simbolisme daripada para penjajah yang sedang terbelenggu yang sedang diikat. Dengan bekal ilmu dan perjuangan keras para penjajah akhirnya terlepas dari ikatan dan Indonesia menjadi bangsa yang merdeka. Manusia harus membekali diri dengan ilmu dan dzikir kepada Allah. sintren gadis berbusana bidadari sama halnya dengan citacita kemerdekaan bangsa Indonesia. Dewasa ini, pemaknaan sintren tidak disamakan lagi dengan cita-cita perjuangan bangsa Indonesia. Namun, sintren dimaknai sebagai cita-cita yang ingin digapai manusia. Apabila manusia ingin mencapai segala kehendaknya, maka manusia harus menjalani sistem-sistem norma yang berlaku terlebih dahulu sebagai kontrol sosial atas segala kehendaknya yang tidak baik, sehingga cita-cita yang diharapkan manusia bisa tercapai dengan baik. ${ }^{30}$

Sintren di Cirebon berawal dari anak-anak pesisir yang menunggu kedatangan orang tuanya yang sedang melaut dengan peralatan yang sederhana anak-anak memainkan kesenian sintren. sintren disimbolkan seperti halnya manusia yang terbebas dari hawa nafsu. Saat penonton melemparkan uang kepada sintren maka sintren akan terjatuh sama halnya dengan manusia yang akan terjatuh ketika terlalu terlena dengan kehidupan duniawi. Sintren adalah sindiran unutuk para pahlawan yang tertangkap oleh penjajah. Dengan menggunakan kata Sapa sing lais mengandung arti bahwa

\footnotetext{
${ }^{29}$ Hasil Wawancara dengan A.Opan Safari, M.Hum selaku tokoh akademisi pada hari Jumat tanggal 16 Desember 2016 pukul 13.00 WIB.

${ }^{30}$ Ibid,.
} 
siapa yang sial tertangkap oleh Belanda. ${ }^{31}$ Untuk memainkan pertunjukan sintren diperlukan latihan menari secara rutin. Seorang pemain sintren harus menguasai lima tarian topeng terlebih dahulu. Dengan keadaan tak sadarkan diri seorang dalang sintren menari dengan gemulai. ${ }^{32}$

\section{KESIMPULAN}

Setelah melakukan pembahasan mengenai pertunjukan kesenian sintren dan nilai-nilai filosofisnya, penulis dapat mengambil kesimpulan sebagai berikut:

Sintren adalah kesenian tradisional yang tumbuh dan berkembang di kalangan masyarakat Cirebon. Sintren merupakan kesenian yang sederhana dengan menggunakan perlengkapan yang sederhana. Sintren terdiri dari dua suku kata yaitu Sinyo yang berarti pemuda dan trennen yang berarti berlatih. Secara etimologi Sintren merupakan gabungan dari dua suku kata yaitu $S i$ yang berarti ia atau dia dan Tren berarti tri atau panggilan lain kata putri. Sehingga Sintren adalah Si Putri yang menjadi pemeran utama dalam kesenian sintren. Sintren mulai diperkenalkan di kalangan masyarakat sekitar tahun 1940, Sintren merupakan bagian dari cerita rakyat yang dalam pagelaran pementasannya seorang penari menari dengan gerak ritmik sangat indah dalam kondisi tidak sadarkan diri seperti halnya fana yang dilakukan oleh para sufi. Kesenian sintren terus berkembang mengikuti arus perkembangan zaman.

Sintren merupakan kesenian tradisional yang bernuansa mistis, yang berasal dari kisah asmara Sulandono dan Sulasih. Sulandono sebagai putra dari Ki Baurekso. Hubungan asmara antara Sulandono dan Sulasih yang tidak direstui oleh Ki Baurekso. Akhirnya Sulandono pergi meninggalkan kampung halamannya untuk bertapa sedangkan Sulasih memilih mengisi

\footnotetext{
${ }^{31}$ Hasil Wawancara dengan Pangeran Hasan selaku tokoh Budayawan Sintren pada tanggal 18 Februari 206 pukul 09.00 WIB.

${ }^{32}$ Hasil wawancara dengan Leni Selaku pemain Sintren pada tanggal 18 Februari 2016 pukul 10.23 WIB.
} 
hari-harinya menjadi seorang penari. Pertemuan antara Sulandono dan Sulasih masih terus berlangsung melalui alam ghaib. Atas bantuan dari ibunda Sulandono yang bernama R.Dewi Rantamsari pertemuan antara keduanya berlangsung. R.Dewi Rantamsari memasukan roh bidadari kedalam tubuh Sulasih, pada saat itu juga Sulandono yang sedang bertapa dipanggil oleh roh ibunya untuk menemui Sulasih. Atas dasar kisah tersebut setiap diadakan pertunjukan Sintren sang penari dibacakan mantra-mantra untuk memanggil roh bidadari.

Kesenian Sintren tumbuh dan berkembang mengikuti kemajuan zaman. Sebelumnya sintren digunakan sebagai media untuk mengusir para penjajah, pada zaman animisme dan dinamisme sintren digunakan sebagai alat untuk mendekatkan diri dan berkomunikasi dengan arwah para leluhur. Namun pada zaman perkembangan agama Islam di Cirebon Sintren digunakan sebagai media dakwah dalam penyebaran agama Islam. Para wali menyebarkan agama Islam dengan memanfaatkan sarana kesenian sintren sebagai salah satu kesenian tradisional yang dijadikan media dakwah Islam di Cirebon dan sekitarnya. Nilai-nilai Filosofis yang terdapat pada pertunjukan kesenian sinten.

\section{DAFTAR PUSTAKA}

Aliet Noorhayati. Metafisika dalam Tarian Sintren (Filsafat Pantura). Jurnal Yaqzan: IAIN Syekh Nurjati Edisi I/No.2/Juli-Desember, 2015. Amin, Samsul Munir. Ilmu Tasawuf. Jakarta: AMZAH, 2012.

Bakker.SJ, J.W.M. Filsafat Kebudayaan: Sebuah Pengantar. Yogyakarta: PT.Kanisius, 1984.

Daradjah, Zakiah. Perbandingan Agama 1. IAIN Jakarta: Jakarta, 1982.

Hendropuspito. Sosiologi Agama. Kanisius: Yogyakarta, 1983.

Komala, Diah Laksmiwati dkk, SINTREN (Rumah Budaya Nusantara Pesambangan Jati Cirebon: Cirebon. 
Kholil, Ahmad. Agama (Kultural) Masyarakat Pinggiran. UIN-MALIKI PRESS: Malang, 2011

Labib. Memahami Ajaran Tashawwuf. Surabaya: Bintang Usaha Jaya, 2001.

Laksmiwati. Rumah Budaya Nusantara Pesambangan Jati Cirebon. Yogyakarta: Deepublish, 2013.

Notowidagdo, Rohiman. Ilmu Budaya Dasar. Jakarta: PT.RajaGrafindo Persada, 2000.

Ryan Prayogi dan Endang Danial. Pergeseran Nilai-Nilai Budaya pada Suku Bonai sebagai Civic Culture di Kecamatan Bonai Darussalam Kabupaten Rokan Hulu Provinsi Riau. Jurnal Humanika Vol. 23 No. $1,2016$.

Subagya, R. Agama Asli Indonesia. Sinar Harapan: Jakarta, 1979.

Scharf, Betty R. Sosiologi Agama. Prenada Media: Jakarta Timur, 2004.

Sudarto. Metodologi Penelitian Filsafat, Jakarta: RajaGrafindo Persada, 2002.

Suparto, Charim. Deskripsi Kesenian Daerah Cirebon. Dinas Kebudayaan, Pariwisata, Pemuda dan Olahraga Kabupaten Cirebon: Sumber, 2009.

Tumanggor, Rusmin dkk. Ilmu Sosial dan Budaya Dasar. Jakarta: Kencana, 2012. 